of dedicating, in October, 1953, the James Ford Bell Room of the University of Minnesota Library which houses the great Bell Collection of rare books and maps on discovery and exploration.

The five essays, all brief, contribute facets to the general theme of scholarship's debt to discriminating collectors. The first paper by Theodore Blegen, dean of Minnesota's Graduate School, nicely introduces the theme, puinting out the distinguished American company of great collectors with whom Mr. Bell's name is linked: Huntington, Folger, Morgan, McCormick, Newberry, Clements, Ayers, Lenox, Chapin, John Carter Brown, Clark, Arents, John G. White, Coe. Mr. Blegen gives us a thumbnail sketch of Mr. Bell, the man, following with some detail on the genesis of the Bell Collection and its final scope. James Ford Bell's own remarks, entitled "Bound Fragments of Time," state his credo as a collector and reveal the way in which his deep interest in trade provided him the key to collecting. This happy choice of a theme led him to the search for records which reveal the evolution of Western institutions during their spread and interplay with other civilizations throughout the world, especially the western hemisphere, as it was discovered and explored.

In the third essay Stanley Pargellis neatly analyzes the rare book in terms of the essential factors-importance, demand, scarcity.
With the force and conviction which has endeared Mr. Pargellis to his colleagues in research libraries, he insists upon the scholarly value of the genuine article, the rare book itself as contrasted with the reprint or facsimile. Colton Storm, in "The Specialized Collection" and Louis B. Wright, in "American Book Collectors" return, in specific terms, to the theme of the scholar's debt to the great American book collectors-those whose collections have been added as integrated special collections to important research libraries, and those whose collections have been established as separately housed libraries for the use of the public.

The little volume, Book Collecting and Scholarship, is much like the one called Rare Books and Research which was published by the UCLA Library in I95I, and there have been others recently. The one before us is not a monograph reporting new discoveries; it is not a handbook to guide library curators; it really has in it little that is new, except as it places a description of the James Ford Bell Collection into the setting of which is it worthy. On the other hand, it is always good to listen to men who know what they are talking about and who talk about important matters. Many of us will appreciate the trouble which the University of Minnesota has taken to include us in the audience.-Andrew H. Horn, University of North Carolina Library.

\title{
Recent Foreign Books on the Graphic Arts, Bibliography, and Library Science
}

Joseph Gregor, for many years curator of the noteworthy theatre collection of the Austrian National Library, is the editor of a new work that will be unusually useful in all reference collections. It is entitled Der Schauspielführer, and, like Der Romanführer, is being published by the Hiersemann Verlag of Stuttgart. The first volume (1953; 375 pages) deals with German drama from the Middle Ages to about 1930 and contains meticulous and thoughtful résumés of 274 plays, ranging from the Tropus von Bamberg (tenth century) and ending with Carl Sternheim's Der Snob (1920). The second volume (1954; 355 pages) covers modern German drama and the first part of the section on drama in the
Romance literatures. In the second volume, there are résumés of 89 modern German plays, of which the great majority were written since World War I ; 4I Italian plays from the Middle Ages to Pirandello; 60 Spanish, Portuguese and South American plays, ranging from Rojas' $L a$ Celestina to the middle of the nineteenth century, with only one twentieth-century title; and French drama from the Middle Ages to around igro. The third volume, which is scheduled for the spring of 1955, will include modern French drama, Greek, Roman, Scandinavian and Dutch drama, and the older English and American drama. The fourth volume will cover recent English and American drama. 
Slavic and Balkan drama will be represented by the fifth and last volume.

In both volumes published thus far each résume is signed by initials which are identified at the beginning. The sub-sections within each volume are introduced by brief, pertinent comments placing the dramatic literature of the age in the proper perspective from the standpoint of general cultural history. Each entry includes full title, dates of first performance and first printing (if in print, for Gregor wisely includes a few significant pieces available only in manuscript), the number of rôles (male and female), the setting, and frequently a note on the idea of the play. The résumés follow the structure of the plays in detail. Each complete entry averages about one page. There are indexes of authors, titles, subjects (i.e., dramatic forms), first printed editions, and one- and two-act plays.

In the first volume, Gregor reveals a broad understanding of the various periods of German literature in his selections as well as in the treatment of individual titles. There are thirteen sections corresponding to the important periods of German dramatic history. German drama is given more space than that of any other language, but this is a natural and understandable lack of proportion in a work edited by an Austrian and published in West Germany.

In the second volume, the problems of selection were even more difficult, and there could be differences of opinion with regard to plays which have been excluded. For example, students of the modern Spanish stage may well be annoyed to find nothing since Bretón de los Herreros and Hartzenbusch. On the other hand, it must be recognized that the European drama is such an enormous field that the spatial limitations of five volumes of the size of the first two make it possible to include only bonafide classics. The judgment of such an authority as Joseph Gregor is as valid as that of any dramatic critic or historian alive today.

Like Der Romanführer, Der Schauspielführer will be an indispensable title in the reference collection of any college or university library and of most larger public libraries as well. It is the most comprehensive guide to dramatic literature of its type and quality that is available today.

The fifth volume of Der Romanführer (Stuttgart, Hiersemann, 1954; edited by li- brarian Johannes Beer of Bochum, pp. 62II019; DM 26) concludes the series on modern German fiction, with entries from Franz Nabl's Der Odhof to Stefan Zweig's Schachnovelle.

The five volumes of the work that have appeared thus far, two on German fiction from the baroque to naturalism and three on modern German fiction, are an invaluable companion to all studies in German literature. The meticulously detailed and accurate signed résumés are by teachers, scholars, librarians, and book dealers who stand high in their respective professions.

In addition to basic bibliographical information, each entry contains notes on subsequent editions, setting, period (in the case of historical fiction), and type of fiction (i.e., historical, psychological, biographical, etc.). At the end of each summary or group of summaries is a list of the more important publications of the author.

A useful feature of this last volume on German fiction is an author index to all of the first five volumes and a title index to the last three volumes. A title index to the first two volumes appears at the end of the second volume.

It might be well for librarians to note that each volume in Der Romanführer as well as in Der Schauspielführer may be purchased separately.

Universitas Litterarum (Berlin, Walter de Gruyter, 1953-) is a conspectus of all the sciences by authorities in the various fields represented. Edited by Werner Schuder, a Berlin librarian, there will be twenty-seven major articles on as many broad fields of learning and seven articles on the organization of knowledge, edited by Robert Teichl of Vienna. Six fascicles have appeared thus far, covering all of the physical and biological sciences, sociology, public relations, technology, agriculture, history, and political science. The work will be complete in eight fascicles, probably early in 1955. Each fascicle sells for DM6.50.

Each article is divided into three major sections, viz., definitions and position of the subject under discussion among the other sciences, methods, objectives, and present state of research in the subject, and the history of the subject. At the end of each section is a highly selective bibliography in all languages.

The work, when complete, will be a useful 
reference for scholars, librarians, students, booksellers, and others in learned and bookish occupations. The various articles offer quick orientations into major fields of learning, a need frequently felt by those of us who must deal with many different subjects. The last seven essays may well prove to be the most interesting of all to librarians, since they will cover the following subjects: academies of sciences, by Wilfried Oberhummer; scientific research institutes, by Rudolf Geissler; libraries, by Robert Teichl, museums, by August von Loehr; universities, by Fritz von Reinohl; and the study of the book, by Wieland Schmidt.

The linguistic incompetence of most American scholars and librarians is notorious. Perhaps the most iniquitous aspect of the situation is that librarians who do bother to learn another language rarely choose Latin, even though Latin is the one key through which all other western European languages may be learned easily. Moreover, the supreme importance of Latin for intelligent bibliographical studies is obvious to anyone who goes beyond the housekeeping details of librarianship.

For German librarians who want to improve their Latin, Hermann Fuchs has edited Aus Theorie und Praxis der Bibliotheken (Hamburg, Eberhard Stichnote, I952; I47 pages; DM8.50). It contains selections from twenty-two Latin authors who have dealt with libraries and librarianship, beginning with Vitruvius and ranging through Isidore, Richard de Bury, and Cardinal Bessarion to Gabriel Naudé and even two nineteenth century authors.

The selections themselves are often delightful purple patches from the literature of librarianship. Pliny's note on illustrated books, Ammianus Marcellinus on the destruction of the Bibliotheca Palatina in Rome, Isidore's etymology of bibliotheca, Bessarion's letter of 1469 to the Venetian Senate founding the Marciana and Naude's ideas on acquisition and cataloging should be part of every librarian's education. If material of this type is not bait enough to make every employee of college and reference libraries want to improve his Latin, then the advocates of languages for librarians will have few other arguments.

There are detailed notes for each selection, and anyone familiar with the paradigms and the basic syntax will have little trouble in using this text. In addition, there is a full glossary which gives the special meaning of many words not in the dictionary of classical Latin.

From the same publisher comes another useful little reference work for librarians, Otti Gross' Library Terms, Fachausdrücke des Bibliothekswesens und seiner Nachbargebiete, English-Deutsch und Deutsch-English (Hamburg, Eberhard Stichnote, 1952; I63 pages,

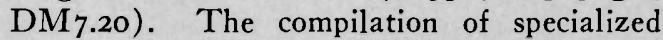
glossaries in any field is a difficult job, and it is a rare work of this sort that makes everyone happy. The American librarian in particular should approach the Gross book with these facts in mind. While it is oriented to English librarianship it is still generally useful for American librarians, especially acquisition librarians and catalogers. Like most other glossaries, this one should be considerably improved in a second edition if the compiler has had the benefit of criticism from those who use it.

The first number of the "Veröffentlichungen des Hölderlin Archivs" (a branch of the Württembergische Landesbibliothek located at Schloss Bebenhausen) is the HölderlinBibliographie, 1938-1950 (Stuttgart, Landesbibliothek, I953; ro3 pages; DMro), edited by Maria Kohler and Alfred Kelletat. The great interest in Hölderlin, intensified during the last two decades, is readily obvious from this bibliography. It is absolutely comprehensive, covering all editions of Hölderlin's works (except selections in anthologies published in Germany) and all critical and biographical notes without regard to value. While the last volume of the Stuttgart Hölderlin edition (now in progress) will contain a bibliography of the more important works about Hölderlin, the HölderlinBibliographie will be an essential tool for any serious student of Hölderlin.

The bibliography is in two parts. The first covers writings by Hölderlin, including first editions, collected editions, partial editions, except editions of individual works, letters, translations, and selections in German anthologies published abroad. Everything, even propagandistic use of Hölderlin's works is included. Part II contains the critical work about Hölderlin, arranged chronologically by years and alphabetically under each year. Reviews are cited with the pertinent 
entry. There are indexes of persons, subjects, and periodicals cited.

An enlightening look into East German librarianship and bibliography is afforded by the series of "Schriften zum Bibliotheks- und Büchereiwesen in Sachsen-Anhalt," edited from the University of Halle Library (now officially the Universitäts- und Landesbibliothek $\mathrm{Halle}$ ) and published by the Otto Harrassowitz division of the VEB Bibliographisches Institut in Leipzig. Three numbers are devoted to personal bibliographies, viz., the work of two noted librarians : No. 2, Carl Wendel, by Horst Kunze, and No. 4, Bernhard Weissenborn, by Willi Göber ; and one philologist, No. 5, Georg Baesecke, by Gertraud Wüstling of Halle. Three titles deal with scientific subjects: No. 7 by Werner Dube, a checklist of articles in German on the work of Ivan Petrovitch Pavlov, the great Russian physiologist; No. 8 by Otto Rübesame, a list of publications on the petroleum geology of the north German plain; and No. 9, by Monika Müller, a checklist of monographs on pest control which have been published in German since 1930.

The three most interesting titles in the series describe the administrative procedures of the University of $\mathrm{Halle}$ Library, which suffered very little damage during the war. No. I is a general description of the Halle Library and its contents by Horst Kunze, and no. 3 is a guide to the use of the library by Kurt Roepke. In both pamphlets a welldeveloped administrative organization is reflected, but it is clear that the totalitarian regime in East Germany has had a definite effect on certain aspects of library service. The most valuable number in the entire series is perhaps no. 6, Dieter Vogel's study of photographic work in Halle. From this little document American librarians interested in photographic reproduction can get some valuable information on equipment and practices in East Germany. The price of the various numbers in this series ranges from fifty pfennig to DM2.75. The first number appeared in 1949, and others have been issued at irregular intervals.

Another series published by $\mathrm{Harrassowitz}$ in Leipzig is entitled "Bibliothekswissenschaftliche Arbeiten aus der Sowjetunion und den Ländern der Volksdemokratie in deutscher Ubersetzung." This series can prove to be unusually useful in providing access to the rich library literature of the U.S.S.R. and other satellite Slavic nations, especially $\mathrm{Po-}$ land and Czechoslovakia. The first number in the series, is a translation important to all students of classification, under the German title of Klassifikation für die Bibliographien der Buchkammer der Sowjetunion mit methodischen Anleitungen zu ihrer Anwendung. The second is an exceptionally interesting statement of propagandistic use of bibliography in the U.S.S.R., L. A. Lewin, Die Klassiker der Marxismus-Leninismus in empfehlenden Bibliographien. Both were published in 1953. It will be a great service to librarianship if more Slavic-language essays on librarianship are made available on a similar basis.

A new annual has been initiated by Palle Birkelund, director of the Royal Library in Copenhagen, for essays on some of the unusual riches of this collection. The title is Fund og Forskning, of which volume I ( 78 pages) appeared last year under the imprint of the library. There are many illustrations, and for each article there is a fully adequate English summary.

Of special interest to us is Mr. Birkelund's essay on John Eliot's Indian Bible, of which the Royal Library owns a copy of the third variant purchased for one silver shilling in I 789 by the celebrated Danish collector Otto Thott. The Royal Library also has a copy of the second edition of 1685 . The remarkable collection of Hebraica in Copenhagen, which is equal or superior to those in Cincinnati and New York, provides for R. Edelmann material for an essay on a fourteenth-century illuminated manuscript of Maimonides' More Nebuchim. The fine collection of bindings in the Royal Library includes three remarkable examples of the work of Nicolas and Clovis Eve, and H. P. Rohde analyzes the reasons for attributing these bindings to the Eves and their association with Henri III. Other essays deal with the early history of the library, sixteenth-century Danish printing, some works by the Danish anatomists Bartholin and Winslow and the rare polemical tracts of Nicolas Steno (bought recently from the collection of the medical historian $\mathrm{V}$. Maar), Danish literature in Dutch translation, the first book printed in Greenland (at Godthaab, in I793), some eighteenth-century Danish silhouettes, and the reception of Karl August Tavaststjerna's work in Denmark. 
Although Frederick Lange Grundtvig, hans Dag og Daad (Copenhagen, Rosenkilde og Bagger, 1954; 86 pages) is not bibliography or library science, it would be improper for the current volume of COLLEGE AND RESEARCH LIBRARIES not to mention it, for the author is one of America's most distinguished senior librarians: Jens Christian Bay. It was written in commemoration of the centennial of the birth of the great Danish-American pastor and scholar, 15 May 1954.

Another anniversary volume celebrates the tenth birthday of the Grafiska Institutet in Stockholm, Grafiska Institutet 1944-1954: Minneskrift (Stockholm, Grafiska Institutet, 1954; II7 pages). It is of special interest in this country inasmuch as the rector, Bror Zachrisson, has been a visiting professor at Carnegie Institute of Technology. Of the several essays in the volume Carl Hultenheim's richly illustrated "En studie i tradition" is especially valuable. Hultenheim examines in some detail the continuity of the Anglo-American typographical tradition and draws a significant moral that modern printers should "work in the company of masterprinters down the ages" (Holbrook Jackson).

Valter Falk, another distinguished Swedish bookman, is the author of Nutida typsnitt, uppkomst och utveckling (Stockholm, Bröderna Lagerstroms förlag, 1954; 174 pages), a series of studies on the most significant modern type faces in use in western Europe in the twentieth century. Introductory chapters discuss the origin of the alphabet and certain pre-twentieth-century types that have had influence in our own day. Subsequent chapters deal with the main lines of modern typographical tradition in Germany, Switzerland, the Netherlands, France, Czechoslovakia, Italy, Spain, England, the United States, and Sweden. The title page is richly illustrated and deserves a place even on the shelves of typographical collections in libraries where the language is not generally read.

Few business firms have played such a vital role in Norwegian cultural as well as commercial life as the firm of J. W. Cappelen. The full story of the crucial early years is told in Einar Boyesen, J.W. Cappelen., 18051878; noen blad av Norsk bokhandels og norsk kulturkamps historie (Oslo, J. W. Cappelen Forlag, 1953; 561 pages, kr.42.00).

When Jørgen Wright Cappelen, a young theological student, decided to go into the publishing business in Oslo in 1826 , he took a step that was to have significant consequences for his native land. His subsequent biography was as much a part of Norway's cultural history as it was his own life. Cappelen's association with the leading literary men of his day in freeing Norway from the domination of the Danish book trade is very important.

Of special value to us are the several chapters on Cappelen's efforts to sell Norwegian books to Norwegian-Americans. Several littleknown facts about the frontier book trade are uncovered and should be exploited by future historians of American bookselling.

An important bibliographical work that has been in progress for almost a half a century is the catalog of manuscripts of the University of Leiden. Although the most recent part of this catalog was issued as far back as 1948 , the entire work ought to be reviewed in view of the fact that further parts are expected soon.

The Leiden collections of manuscripts are so rich and extensive that this catalog is a necessary part of the equipment of any academic library which supports classical, oriental or Germanic studies. Our attention may be concentrated here on the classical manuscripts.

The Leiden Library divides its western manuscripts into three main groups, viz., those named for the previous owner (Codices Vossiani, Scaligerani, Vulcaniani, Hugeniani, Perizoniani, Lipsiani, Papenbroekiani, Petri Cunae, Prosperi Marchand, Burmanniani, Gronoviani, Oudendorpiani, Hemsterhusiani, Ruhnkeniani, Ioannis in de Betouw, Wyttenbachiani, and Guilielmi M. d'Ablaing); the Codices Bibliothecae Publicae Graeci; and the Codices Bibliothecae Publicae Latini and Miscellanei. The first fascicle of the Leiden catalog of manuscripts appeared in 1910 and was devoted to the manuscripts of Bonaventura Vulcanius, acquired by the University of Leiden shortly after Vulcanius' death in I6I4. The second fascicle also appeared in 1910 and listed the manuscripts of J. J. Scaliger, who died in 1609 and willed virtually all of his manuscripts to the library. The third fascicle appeared in 1912 and listed the Codices Bibliothecae Publicae Latini. After a lapse of thirty-four years K. A. de Meyier's catalog of the manuscripts of Jacobus Perizonius (Voorbroek) was published. Dr. de Meyier will 
soon complete his catalog of the Vossius Collection of Greek manuscripts.

A few notes on the Perizonius collection will serve to indicate the general nature of the Leiden catalogs. Perizonius died in I715, and he willed not only the manuscripts but also many rare books and an endowment of 20,000 florins to the University. The manuscripts include Greek and Latin authors as well as later commentaries. Some were described in the rather imperfect catalog by Jacob Geel (1852), and others are described first by de Meyier.

The physical characteristics of each manuscript are noted in detail, and there are, of course, titles and incipits. There are also notes on provenance, editions, and other publications pertaining to each manuscript. Entries are arranged in shelf order (folio, quarto, octavo). There are indices of paleographical information, age, illumination, bindings, scribes, place of origin, former owners, authors, incipits of anonymous works, addressees of letters and persons to whom significant reference is made, and a subject index. The Leiden manuscript catalogs deserve the careful attention of librarians as models of the genre.

At the main entrance of the Lenin Library in Moscow stands a lady police officer with a grim-looking automatic stuck in her belt. A guide told a Norwegian visitor recently: "We do not underrate our enemies. We know the enormous significance of this library for the cultural and economic life of our country. The Americans also know that, and we know very well what the results might be if an American agent could get into this library. An incendiary pencil could be enough to send this cultural treasure up in flames."

This is part of a travel report on Soviet libraries by John Brandrud in the third volume of the Norsk arbok for bibliotek og forskning (1954), published by the Norske Forskningsbibliotekarers Forening with headquarters in the University of Oslo Library. Brandrud's essay, the leading article, reveals many interesting facts about the Lenin $\mathrm{Li}$ brary in particular.

Apparently only a small proportion of the $16,000,000$ volumes in the Lenin Library are unduplicated titles, for the Lenin Library serves as a popular library as well as a research collection. Brandrud takes some in- teresting samples of the Lenin Library's holdings, and it would seem that the actual research strength of the collection is not much greater, if any greater, than that of any one of the major middle-western university libraries.

Other essays in this volume deal with indexing, the manuscript division of the University of Oslo Library, the Statistical Central Bureau's library in Oslo, periodicals in reference libraries, cooperation between libraries and schools, bookmobiles in Norway, the Bibliographical Center in Denver, the community library service for municipal administrators in Sweden, public documents, post-war binding problems, circulation systems in public libraries, English county libraries, and the Institut de Recherche et d'Histoire des Textes in Paris. There is an English summary at the end of each article. In addition, there is a short review section and a section listing selected library literature in 1953-54. A supplement listing Norwegian authors, I88II920, by W. P. Sommerfeldt will prove valuable to catalogers.

The fourth volume of the Jahrbuch der Auktionspreise für Bücher, Handschriften und Autographen (Hamburg, Dr. Ernst Hauswedell, 1954; 442 pages; DM 48), covering 1953, appeared in the autumn of the year following the one for which auctions were reported. In the future it is expected to have each volume in print in the spring following the year for which auctions are reported, thus increasing the value of the work considerably for librarians, dealers, and collectors.

The main part of the work is divided into three sections, viz., auction prices for printed books, for historical and literary manuscripts, and for holographic manuscripts (including letters, texts, and other significant personalia).

In addition, there are other useful features -a list of auctions in 1953, a table of monetary exchange rates, a list of abbreviations, a list of professional associations of antiquarian booksellers in all countries, special fields of booksellers in all countries (alphabetically by subject), and the addresses of booksellers included in the specialty list and the advertisements. There is also a short bibliographical guide to the literature of bookbinding history excerpted from volume I of Helmut Helwig's recently published Handbuch der Einbandkunde. 
One of the most instructive uses of the Jahrbuch der Auktionspreise is a comparative study of the prices with those reported for England and the United States. In general, rarissima and books running into four figures and more command about the same prices as they would anywhere else in the world. On the other hand, it would seem that American libraries might well find it to their advantage to bid more extensively than they do at present at European auctions for books ranging from ten to around two or three hundred dollars.

A sample check of twenty-five pieces of Americana in the current Jahrbuch indicated an average difference of 30 per cent between European and American prices. It would be worthwhile for a detailed study of the comparative price situation to be made every five or six years as a matter of information to American reference libraries.

Outside of the English-speaking world, the field of jurisprudence, as an academic discipline, includes many fields normally assigned to the social studies in our universities. As a result, the fifth edition of Wilhelm Fuchs' now almost classic Juristische Bücherkunde (Göttingen-Grone, August Schönhutte, I953; v. I, "Geschichte und System der juristischen Fachbibliographie," 506 pages; DM 34.20) is a basic reference work not only for students of law, but also for social scientists in general.

Fuchs goes into every aspect of legal bibliography. The first part of this volume is devoted to a history of the development of legal bibliography from the invention of printing up to the middle of the twentieth century. The second part, which accounts for about 90 per cent of the text, covers the theory and technique of legal bibliography and gives a critical list of references in narrative rather than enumerative form.

Fuchs' bibliographical citations are, in general, meticulously correct with a minimum of typographical errors in non-German titles, and his critical comment indicates a direct personal acquaintance with his material.

Some of the chapters are good introductions to other broad fields of bibliography. For example, the chapters on public documents, manuscripts and incunabula, anonymous and pseudonymous literature, and the bibliography of academy publications, serials, university publications indicate that Fuchs is as well acquainted with the special problems of these genres as he is with legal bibliography.

In addition to his broad interpretation of jurisprudence and his listing of pertinent reference works, Fuchs also has special chapters on auxiliary disciplines, viz., history, philology, religion, philosophy, social studies, and medicine.

A comparison with earlier editions indicates clearly that the present edition of Fuchs is a complete revision. Numerous books and serials that appeared as late as 1952 are discussed, and supplements to and new editions of older books are noted.

When Heinz Otto Burger's Geschichte der deutschen Literatur (Stuttgart, Metzler, 1952; 882 pages; DM 10) appeared in 1952, it was recognized at once as one of the best available histories of German literature. In the same year K. H. Halbach published the supplement to Burger, Vergleichende Zeittafel zur deutschen Literaturgeschichte (ibid.; 52 pages; DM 4.50). Last year a second supplement appeared, Otto Olzien's Bibliographie zur deutschen Literaturgeschichte (ibid., 1953; I56 pages; DM 15). Although all three parts form a single inseparable reference work of considerable value, Olzien's contribution is the one that will interest librarians in particular.

Olzien has made no effort to provide a definitive bibliography of Germanistic studies, and his work supplements rather than rivals the important Bibliographisches Handbuch des deutschen Schriftums (Bern, Francke, 1949; third edition; 644 pages) by Josef Körner. Olzien lays special emphasis on the most recent critical literature, especially that published between the closing date for Körner and 1952. On the other hand, many periods of German literature are inadequately covered by post-war scholarship, and therefore Olzien has frequently had to refer to earlier works, especially for writers of the fourteenth, fifteenth, and sixteenth centuries.

There are three major sections, the general one (including bibliographies, reference works, periodicals, critical and historical series of texts, methodology, general histories, regional histories, histories of genres), the chronological one including studies of whole periods or aspects of periods, and individual authors (alphabetical). The special value of this bibliography for librarians lies in its use- 
fulness as a guide for checking library holdings in German literature and as a ready reference work. It does not, however, supplant Körner and Goedeke, nor does it pretend to do so.

Hans Volz' Hundert Jahre Wittenberger Bibeldruck, 1522-1626 (Göttingen, Verlag Dr. Ludwig Häntzschel, I954; 168 pages; DM Io), is the first in a new series edited by Karl Julius Hartmann under the general title of "Arbeiten aus der Staats- und Universitätsbibliothek Göttingen." This series succeeds the old "Hainbergschriften" issued at Göttingen.

Volz, who has been closely identified with the great Weimar edition of Luther's works, is one of the best informed of all students of Reformation bibliography. In this study he gives the first comprehensive survey of Bible printing in the first century of the Reformation in Luther's own headquarters, Wittenberg.

It has long been widely known that the University of Göttingen Library (now officially known as the Niedersächische Staatsund Universitätsbibliothek) has the most extensive holdings of Luther imprints in West Germany. Much of the strength of Göttingen in this field may be attributed to the remarkable Oskar Mulert Collection.

Supplementing the material available at Göttingen with information garnered from questionnaires sent to all major German research libraries, Volz has composed a comprehensive study of the textual history, design and illustration, printing, distribution, reprinting, size of editions, and prices of the Wittenberg Bibles. $\mathrm{He}$ includes Bibles in both High and Low German. Supplements give a tabular bibliography of the various Bibles printed during the period under consideration, a checklist by printers, and a chart of the printing history of Wittenberg during the period.

Volz' thorough knowledge of the period with which he was dealing and his ability to coordinate the history of printing and publishing with general cultural history give this study a special significance. It will prove as useful to students of political and religious history as to librarians and bibliographers.

In I 896 Erik Thyselius published a bibliography of official reports of Swedish government committees entitled Förteckning ofver komitébetänkanden afgifna under ären 1809 1894, and in 1904 he published a supplement under the same title covering the years $1895-$ 1904. In 1944, the Swedish Riksdagbibliotek (library of parliament) decided to bring Thyselius up to date and include printed and manuscript committee reports, departmental memoranda, and certain Riksdag reports. The volume finally appeared after almost a decade under the title Förteckning över statliga utredningar 1904-1945 (Norrköping, Ostergötlands tryckeri, 1953; I405 pages). Of the 5,206 numbers in the bibliography, some I,900 were compiled by former Riksdag librarian Ivar Beskow. The job was completed by Beskow's successor, Anders Lindberger.

The arrangement is by government department and chronologically under each department. There are indexes of personal names and subjects and a chronological index. Some $I, 150$ of the documents recorded in this bibliography are in manuscript.

Major document bibliographies of this sort are especially needed in many countries where there has not been a continuing tradition of document bibliography over a long period. A good many other parliamentary libraries in smaller countries throughout the world could perform an important service to librarianship and bibliography by issuing similar compilations.

A variant approach to the bibliographical problem represented by the Index Translationum may be seen in the new Bibliographie der Ueberstzungen deutschsprachiger Werke, issued by the Deutsche Bücherei in Leipzig. The first number, which appeared in 1954, begins with translations of German-language books into foreign languages that were published in I95I. It is planned ultimately to issue the bibliography quarterly, but it will appear more frequently until the listings become current.

The new Zeitschrift für Bibliothekswesen und Bibliographie, of which volume one, numbers one and two appeared in 1954, is intended to be the West German counterpart to the Zentralblatt für Bibliothekswesen.

Although the $Z f B$ still maintains a high quality of scholarship in its main articles and bibliographical sections, there is some annoying evidence of Volksdemokratie in almost every issue at one point or another. One can hardly blame the West German librarians for starting a new journal in the light of this circumstance. 
The new $Z B B$ (if we may coin this abbreviation on the model of the time-honored $Z f B)$ is edited by H. W. Eppelsheimer of Frankfurt, G. Hofmann of Munich, and $\mathrm{H}$. Tiemann of Hamburg. Editorial communications should be addressed to Dr. H. Middendorf at the Bayerische Staatsbibliothek in Munich. The publisher is Vittorio Klostermann of Frankfurt, and four issues per annum carry a subscription price of DM 33.50.

Articles in the first issue are by Eppelsheimer on libraries and documentation and by $F$. A. Schmidt-Künsemüller on planned periodical acquisition by the Deutsche Forschungsgemeinschaft. In the second number
C. Köttelwesch writes on problems of interlibrary loan in Germany, K. Lelbach on the Bonn student library, $H$. Fuchs on the late Hugo Andres Krüss, and Eppelsheimer on the current status of German literary bibliography. In each issue there is a checklist of current bibliographical literature which may well turn out to be comparable in scope and extent to that in the $Z f B$. There are, of course, reviews and news notes.

COLLEGE AND RESEARCH LIBRARIES extends a cordial welcome to the $Z B B$ into the family of library periodicals and wishes it the same distinction attained by the old $Z f B$.Lawrence S. Thompson, University of Kentucky Libraries.

\section{Communication of Specialized Information}

The Communication of Specialized Information. Papers Presented before the Seventeenth Annual Conference of the Graduate Library School of the University of Chicago August II-15, 1952. Edited by Margaret E. Egan. Chicago: American Library Association, 1954. 128p. \$4.00.

The Papers Presented before the Seventeenth Annual Conference of the Graduate Library School of the University of Chicago August II-15, 1952, previously published in American Documentation IV, nos. 3 and 4, 1953, are now available in a monograph edited by Margaret E. Egan. Except for a preface by Miss Egan, the content of the papers is identical with their first appearance in $A m e r i-$ can Documentation. The topic of the Conference was the communication of specialized information from which the book takes its title. By this term is meant those research records, articles, essays, and the like which usually appear in near-print format in restricted editions, particularly as to distribution or use, and which take significance because of their timeliness and are especially valuable to subject specialists in technical fields of knowledge. This material, the lifeblood of the highly specialized library, from the traditional library point of view, is considered ephemeral. Other words which have been used to describe this kind of information and its organization are documentation and technical information. The titles of the papers of the participants in the conference which follow, indicate the vast area in com- munications which this type of information encompasses:

"The Problem of Specialized Communication in Modern Society," Verner W. Clapp.

"New Patterns in Scientific Research and Publication," Eugene W. Scott.

"The Distribution-Acquisition Problem in Technical Reporting," Eugene E. Miller.

"Organizing and Servicing Unpublished Reports," Dwight E. Gray.

"Restricted Dissemination of Information and Its Social Implications," Robert Tumbleson.

"Implications for Professional Organization and Training," Mortimer Taube.

"Contemporary Trends in the Production and Use of Social Data," Morris B. Ullman.

"The Use of Social Data by Business, Finance, and Industry," Margaret E. Egan.

"Industrial Relations-A Case Study of Specialized Communication Involving Several Groups," Frederick H. Harbison.

"Emergence of a New Institutional Structure for the Dissemination of Specialized Information," Jesse H. Shera.

As seen at once, the conference posed serious questions for the library profession. The very nature of the material under consideration, its handling and organization, challenges the traditional techniques and practices in use in libraries today. But there is too much here to attempt to analyze in detail. The papers are all worth reading and should become an essential part of professional library literature.

The format of this monograph, however, distributed by the American Library Associa- 